Abstracta Iranica Abstracta Iranica

Revue bibliographique pour le domaine irano-aryen

Volume 32-33 | 2013

Comptes rendus des publications de 2009-2010

\title{
Barbara Kaim. Investiture or Mithra. Towards a new interpretation of so called investiture scenes in Parthian and Sasanian Art
}

Rika Gyselen

\section{OpenEdition \\ 1 Journals}

Édition électronique

URL : http://journals.openedition.org/abstractairanica/40544

DOI : $10.4000 /$ abstractairanica.40544

ISSN : 1961-960X

Éditeur :

CNRS (UMR 7528 Mondes iraniens et indiens), Éditions de l'IFRI

\section{Édition imprimée}

Date de publication : 1 décembre 2013

ISSN : 0240-8910

Référence électronique

Rika Gyselen, « Barbara Kaim. Investiture or Mithra. Towards a new interpretation of so called investiture scenes in Parthian and Sasanian Art », Abstracta Iranica [En ligne], Volume 32-33 | 2013, document 180, mis en ligne le 01 juillet 2016, consulté le 05 octobre 2020. URL : http://journals.openedition.org/ abstractairanica/40544; DOI : https://doi.org/10.4000/abstractairanica.40544

Ce document a été généré automatiquement le 5 octobre 2020.

Tous droits réservés 


\title{
Barbara Kaim. Investiture or Mithra. Towards a new interpretation of so called investiture scenes in Parthian and Sasanian Art
}

\author{
Rika Gyselen
}

\section{RÉFÉRENCE}

Barbara Kaim. « Investiture or Mithra. Towards a new interpretation of so called investiture scenes in Parthian and Sasanian Art ». Iranica Antiqua, vol. XLIV, 2009, p. 403-415.

1 Sur dix reliefs rupestres sassanides, la scène principale comporte une 'divinité' présentant un anneau endiadémé à un roi. À quelques rares exceptions près, de telles représentations ont été interprétées comme une investiture du roi par une 'divinité'. L'A. met en évidence que dans plusieurs cas l'anneau, endiadémé ou non, est le symbole d'un engagement contracté entre deux personnes, et pas nécessairement celui d'une investiture.

\section{AUTEURS}

RIKA GYSELEN

CNRS/Mondes iranien et indien, Paris 